\title{
FAKTOR-FAKTOR YANG MEMPENGARUHI NILAI PRODUKSI INDUSTRI PERABOT DI KECAMATAN JEUMPA KABUPATEN BIREUN
}

\author{
Devi Andriyani ${ }^{\text {a1 }}$, Agus Susanti ${ }^{\text {a2 }}$ \\ ${ }^{a}$ Fakultas Ekonomi dan Bisnis Universitas Malikussaleh \\ 1Corresponding author : devisep80@gmail.com \\ 2 agussusanti22774@gmail.com
}

\section{A R T I CLE I N F O RMA T I O N}

A B S T R A C T

\section{Keywords:}

Labor, Investment Value, Raw Material Cost, Production Value.
This study aims to analyze the Factors that Influence the Value of Furniture Industry Production in the Sub-district of Jeumpa Bireuen Regency in 2017. The data used in this study is secondary data. The method use to analyze is the multiple Linear Regression. The results of the research are partially Labor and Investment had a positive and significant effect on the Value of Furniture Industry Production in the Sub-district of Jeumpa District Bireuen Regency. Raw Material costs did not affect the Value of Furniture Industry Production. Simultaneously Labor, Investment and Raw Material Cost had a positive and significant effect on the Production Value of Jeumpa Subdistrict Funiture Industry.

\section{PENDAHULUAN}

Sektor industri dijadikan sebagai sektor yang memiliki peranan sangat penting untuk memacu sektor lainnya. Pembangunan industri perabot yang berkembang di Kabupaten Bireuen merupakan salah satu dari pelaksanaan pembangunan dan pola dasar pembangunan masyarakat adil dan makmur. Ada beberapa faktor yang telah menyebabkan industri ini berkembang dengan baik. Faktor utamanya adalah modal kerja dan tenaga kerja.

Berikut adalah data kondisi industri perabot di Kabupaten Bireun :

\section{Tabel 1}

\section{Data kondisi industri perabot di Kabupaten} Bireuen Tahun 2017

\begin{tabular}{|c|c|c|c|c|}
\hline Nama & $\begin{array}{c}\text { Nilai } \\
\text { Produksi } \\
(\mathrm{Rp})\end{array}$ & $\begin{array}{c}\text { Biaya } \\
\text { Tenaga } \\
\text { Kerja } \\
(\mathrm{Rp})\end{array}$ & $\begin{array}{c}\text { Nilai } \\
\text { Investasi } \\
(\mathrm{Rp})\end{array}$ & $\begin{array}{c}\text { Biaya } \\
\text { Bahan } \\
\text { Baku (Rp) }\end{array}$ \\
\hline Nasruddin & 4.040 .000 & 6.000 .000 & 70.000 .000 & 50.000 .000 \\
\hline Fauzi & 1.000 .000 & 3.000 .000 & 20.000 .000 & 50.000 .000 \\
\hline Asrul & 9.500 .000 & 3.000 .000 & 20.000 .000 & 50.000 .000 \\
\hline Fadli & 1.400 .000 & 4.500 .000 & 30.000 .000 & 50.000 .000 \\
\hline M uzakkir & 9.500 .000 & 3.000 .000 & 20.000 .000 & 70.000 .000 \\
\hline
\end{tabular}

Sumber: Data dari Dinas Perindustrian, Tahun 2017
Pada Tabel 1 di atas terlihat bahwa pemilik perusahaan Fauzi, Asrul dan Muzakkir memiliki jumlah Biaya Tenaga Kerja yang sama yaitu Rp.3.000.000, tetapi Nilai Produksi yang dihasilkan berbeda, namun Biaya Bahan Baku hanya berbeda pada Muzakkir yang Biaya Bahan Bakunya Rp.70.000.000 dibandingkan dengan Fauzi dan Asrul. Hal ini tentu tidak sesuai dengan teori yang menyatakan penambahan jumlah Biaya Tenaga Kerja akan menambah Nilai Produksi (Sumarsono, 2003).

Nilai Investasi Fauzi dan Asrul sama, tetapi menghasilkan Nilai Produksi yang sama. Hal ini tentu tidak sesuai dengan teori semakin besar nilai investasi maka akan semakin tinggi nilai produksinya (Sukirno, 2012). Pada tingkat investasi yang sama seharusnya menghasilkan nilai produksi yang sama.

Fenomena yang lain yang dapat dilihat dari Tabel diatas adalah Biaya Bahan Baku yang paling tinggi digunakan oleh Muzakkir yaitu Rp.70.000.000, seharusnya dengan pemakaian biaya bahan baku yang besar akan menghasilkan Nilai Produksi yang tinggi (Riyanto, 2002). Tetapi yang terlihat di tabel diatas Nilai Produksi yang 
tinggi dicapai oleh Nasruddin yang hanya menggunakan Biaya Bahan Baku Rp.50.000.000.

Penelitian ini bertujuan untuk mengetahui dan menganalisis pengaruh dari tenaga kerja, nilai investasi, danbiaya bahan baku terhadap nilai produksi industri perabot di Kecamatan Jeumpa Kabupaten Bireuen.

Selanjutnya pembahasan dibagian kedua dalam artikel ini adalah tinjauan teori, dibagian ketiga dibahas tentang metode penelitian. Pada bagian keempat membahas hasil dan pembahasan dan akhirnya tutup dengan kesimpulan dan saran pada bagian kelima.

\section{TINJAUAN TEORITIS}

\section{Nilai Produksi}

Menurut Sumarsono (2003), nilai produksi adalah nilai hasil akhir proses produksi pada suatu sektor industri kecil maupun besar berdasarkan bidang usaha.

Hasir (2013), menurut penelitiannya menyatakan bahwa nilai produksi yang dihasilkan dalam satu tahun yang dinyatakan dalam satuan rupiah, jumlah tenaga kerja mempengaruhi nilai produksi.

Menurut Sudarsono (2007), nilai produksi adalah tingkat produksi atau keseluruhan jumlah barang yang merupakan hasil akhir proses produksi pada suatu unit usaha yang selanjutnya akan dijual sampai kedatangan konsumen, naik turunnya permintaan pasar akan hasil produksi untuk menambahkan kapasitas produksinya.

Menurut Sugiarto \& Dkk (2007), nilai produksi adalah suatu kegiatan yang mengubah input menjadi output.

\section{Biaya Tenaga Kerja}

Menurut Simamora (2000), Biaya Tenaga Kerja adalah biaya yang dikeluarkan untuk pekerja atau karyawan yang dapat ditelusuri secara fisik kedalam pembuatan produk dan bisa pula ditelusuri dengan mudah atau tanpa biaya banyak.

Permintaan akan tenaga kerja bersifat deriverded yang berarti bahwa permintaan tenaga kerja oleh pengusaha sangat tergantung pada permintaan masyarakat terhadap hasil produksinya. Sehingga mempertahankan tenaga kerja yang diguakan perusahaan, maka perusahaan harus memiliki kemampuan bersaing untuk asset dalam negri maupun luar Negri. Oleh karena itu perusahaan harus benar-benar mempunyai tenaga kerja yang memang mampu membawa perusahan untuk menghadapi persaingan. Salah satu faktor yang mempengaruhi permintaan tenaga kerja adalah naik turunnya permintaan pasar akan hasil produksi dari perusahaan yang bersangkutan (Sumarsono, 2003).

Budiman (2015), menjelaskan bahwa Biaya Tenaga Kerja memiliki pengaruh positif dan signifikan terhadap pendapatan.

Hasir (2013), Biaya Tenaga kerja mempengaruhi nilai produksi, bagi perusahaan produksi yang memegang peranan penting dalam kegiatan usaha industri perabot.Penggunaan tenaga kerja bertujuan untuk mengatur dan mengolah bahan pabu pada perusahaan industri perabot.

\section{Nilai Investasi}

Menurut Sukirno (2004), investasi adalah nilai investasi penanaman modal pada sektor industri di Kabupaten Bireuen yang digunakan untuk memenuhi keperluan perlengkapan produksi dalam menunjang kemampuan perusahaan industri yang ada.

Nilai investasi mempengaruhi nilai produksi, kegiatan produksi memerlukan modal didalam memproduksi suatu barang.Nilai investasi merupakan modal untuk membeli perlengkapan barang produksi, tujuan dari nilai investasi untuk menambah kempuan memproduksi barang-barang industri perabot.

Prasetyo \& Dkk (2005), mengemukakan bahwa investasi mempunyai pengaruh yang signifikan terhadap penyerapan tenaga kerja yang artinya semakin besar investasi yang diterima maka akan besar pula penyerapan tenaga kerja.

Simamora (2000), investasi adalah suatu aktiva yang digunakan oleh perusahaan untuk menambah atau pertumbuhan kekayaan melalui distribusi hasil investasi, misalnya pendapatan bunga, royalti, deviden serta pendapatan sewa lainnya.

Menurut Tandelin (2010), investasi adalah komitmen atau sejumlah dana atau sumber dana lainnya yang dilakukan pada saat ini, dengan tujuan 
memperoleh sejumlah keuntungan dimasa yang akan.

\section{Biaya Bahan Baku}

Biaya Bahan Baku merupakan biaya untuk persedian Bahan Baku guna untuk menghasilkan jumlah produk yang semakin banyak. Setiap perusahaan yang menyelenggarakan kegiatan produksi akan memerlukan Bahan Baku.

Menurut Muktianji (2006), Bahan baku akan mempengaruhi nilai produksi Bahan baku merupakan bahan yang utama dibutuhkan dalam melakukan proses produksi sampai menjadi barang jadi. Bahan baku meliputi semua barang dan digunakan untuk proses produksi.

Riyanto (2002), biaya bahan baku biaya bahan jadi atau barang setengah jadi Tanpa bahan baku jelas tidak ada barang jadi. Biaya bahan baku adalah bahan baku yang dipakai untuk membuat produk dalam satuan uang dimana pekalian kuantitas standar bahan baku dikali harga standar bahan baku per unit.

Suartawan \& Purbadharmaja (2019), menurut penelitiannya produksi sebagai variabel yang mampu memberikan tidak berpengaruh terhadap hubungan bahan baku dan pendapatan.

Mardiasmo (2007), biaya baku adalah biaya perolehan dasar yang digunakan membeli bahan untu memulai kelancaran dalam proses produksi.

Prawirosentono (2007), secara umum bahan baku merupakan bahan mentah yang menjadi barang dasar pembuatan suatu produk yang diolah melalui proses tertentu untuk dijadikan produk tertentu agar memiliki nilai tambah yang lebih tinggi.

Budiman (2015), menurut penelitiannya bahan baku berpengaruh positif dan signifikan terhadap nilai produksi di provinsi Riau.

\section{Kerangka Konseptual}

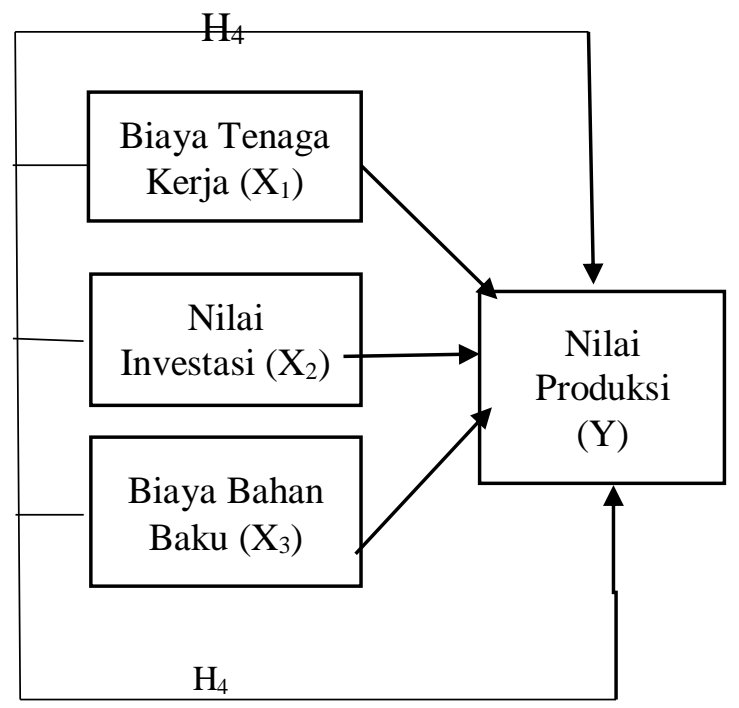

Gambar 1.

\section{Kerangka Konseptual}

Kerangka konseptual gambar 1 di atas menjelaskan pengaruh antara variabel bebas dan variabel terikat, yaitu pengaruh tenaga kerja (x1), nilai investasi (x2) dan biaya bahan baku (x3) terhadap nilai produksi (y) yang akan di uji secara parsial dengan mengguakan uji $t$, dan secara bersama-sama seluruh variabel independen terhadap dependen dengan menggunakan uji f.

\section{Hipotesis}

Adapun hipotesis alternatif yang diberikan dalam penelitian ini adalah sebagai berikut :

$\mathrm{H}_{1}$ : Diduga Biaya Tenaga Kerja berpengaruh positif dan signifikan terhadap Nilai Produksi.

$\mathrm{H}_{2}$ : Diduga Nilai Investasi berpengaruh positif dan signifikan terhadap Nilai Produksi.

$\mathrm{H}_{3}$ : Diduga Biaya Bahan Baku berpengaruh positif dan signifikan terhadap Nilai Produksi.

$\mathrm{H}_{4}$ : Diduga Biaya Tenaga Kerja, Nilai Investasi dan Biaya Bahan Baku berpengaruh signifikan terhadap Nilai Produksi.

\section{METODE PENELITIAN}

\section{Data dan Sumber Data}

Penelitian ini menggunakan data sekunder, yang dimaksud dengan data sekunder adalah data yang telah diolah oleh pihak lain. Data yang 
digunakan tahun 2017. Data utama di dalam penulisan proposal ini bersumber dari Dinas Perindustrian.

\section{Definisi Operasionalisasi Variabel}

Operasionalisasi variabel merupakan petunjuk bagaimana variabel-variabeldalam penelitian diukur. Untuk memperjelas dan mempermudah pemahaman terhadap variabel-variabel yang akan dianalisis dalam penelitian ini, maka butuh dirumuskan operasionalisasi variabel yaitu sebagai berikut:

1. Nilai produksi adalah harga dari keseluruhan hasil produksi yang terjual, dengan satuan Rupiah (Rp).

2. Biaya Tenaga kerja adalah orang yang menghasilkan produksi dengan asumsi gaji satuan Rupiah (Rp).

3. Nilai Investasi adalah uang yang dipakai untuk melakukan kegiatan produksi, dengan satuan Rupiah ( $\mathrm{Rp}$ ).

4. Biaya Bahan Baku adalah biaya bahan dasar yang digunakan untuk proses produksi, dengan satuan Rupiah ( $\mathrm{Rp}$ ).

\section{Metode Analisis Data}

Untuk menganalisis pengaruh variabel bebas dan variabel terikat digunakan teknik regresi linear berganda dengan formula OLS (Ordinary Least Quare), yaitu :

$$
\mathrm{Y}=\alpha+\beta 1 \times 1+\beta 2 \times 2+\beta 3 \times 3+e i
$$

Dimana :

Y : Nilai Produksi

$\mathrm{X}_{1}$ : Tenaga Kerja

$\mathrm{X}_{2}$ : Nilai Investasi

$\mathrm{X}_{3}$ : Biaya Bahan Baku

ei : Error Term

\section{Uji Normalitas}

Menurut Gujarati (2009), menyebutkan bahwa uji normalitas adalah suatu pengujian dimana jika probabilitasnya lebih besar daripada alpha 5 persen maka uji normalitas diterima. Justifikasi lainnya untuk uji ini adalah dengan membandingkan nilai J-B hitung dengan $\mathrm{x} 2$ tabel , apabila alpha J-B <x2 tabel maka residual terdistribusi normal. Sedangkan menurut Sunyoto
(2011), uji normalitas adalah pengujian yang akan menguji data variabel bebas (x) dan data variabel terikat (y) pada persamaan regresi yang dihasilkan berdistribusi normal atau berdistribusi tidak normal.

Model regresi yang baik merupakan berdistribusi data normal atau mendekati normal.Metode yang sering digunakan untuk melakukan uji normalitas adalah dengan uji Jarquebera. Pengujian ini dapat dilakukan dengan program EVIEWS sehingga nantinya memperoleh nilai probabilitas (p-value). Jika nilai probabilitasnya lebih besar dari $5 \%(<0,05)$, berarti nilai residual berdistribusi normal. Sebaliknya, jika nilai probabilitas lebih kecil dari $5 \% \quad(<0,05)$, berarti nilai residualnya berdistribusi tidak normal.

\section{Pengujian Asumsi Klasik}

Dalam melakukan estimasi persamaan linier dengan menggunakan metode OLS, maka asumsiasumsi dari OLS harus dipenuhi.

Berdasarkan keadaan tersebut didalam ilmu ekonometrika agar suatu model dikatakan baik maka perlu dilakukan pengujian sebagai berikut :

\section{Uji Autokorelasi}

Menurut Ghozali (2006), ada beberapa cara yang dapat digunakan untuk melihat terjadi atau tidaknya Autokorelasi. Salah satunya dengan Uji Breusch-Godfrey Serial LM Test.

\section{Uji Multikolineritas}

Multikolineritas adalah suatu kondisi dimana terjadinya korelasi yang kuat diantara variabel-variabel (x) yang di ikut sertakan dalam pembentukan model regresi linear (Gujarati, 2006). Uji multikolineritas dilakukan untuk melihat apakah dalam model regresi ditemukan adanya korelasi antar variabel bebas (x).Jika terjadi korelasi yang tinggi, maka regresi tersebut terjadi multikolineritas.

Untuk mengetahui multikolineritas dengan menggunakan Eviews dapat dilakukan dengan melihat korelasi antar variabel bebas (Correlation Matrik). Jika korelasi antara variabel bebas lebih atau sama dengan $0,8 \quad(<0,8)$, berarti terjadi multikolineritas. 


\section{Pengujian Statistik}

Untuk menguji kebenaran model regresi diperlukan pengujian statistik diantaranya :

\section{Uji t-Statistik}

Menurut Ghozali (2006), uji statistic atau uji $\mathrm{t}$ bertujuan untuk melihat signifikan dari pengaruh variabel bebas secara individual terhadap variabel terikat dengan menganggap variabel bebas lainnya adalah konstan.

1. Jika t hitung > t tabel, maka variabel penjelas secara individual mempengaruhi variabel yang dijelaskan secara signifikan.

2. Jika $\mathrm{t}$ hitung $<\mathrm{t}$ tabel, maka variabel penjelas secara individual tidak mempengaruhi variabel yag dijelaskan secara signifikan.

\section{Uji F-statistik}

Untuk menentukan tingkat signifikan secara keseluruhan pada tingkat kepercayaan sebesar 95\%, pengujian hipotesis dengan uji $\mathrm{F}$. Gujarati (2006), uji F dilakukan dengan membandingkan antara $\mathrm{F}$ hitung dengan $\mathrm{F}$ table, apabila $\mathrm{F}$ hitung $>\mathrm{F}$ table, dicari di tabel $\mathrm{F}$ dengan patokan taraf signifikan 5\%, artinya bahwa $\left(\mathrm{X}_{1}\right)$, $\left(\mathrm{X}_{2}\right)$, dan $\left(\mathrm{X}_{3}\right)$, secara bersama-sama mempengaruhi (Y).

\section{Koefisien Determinasi $\left(\mathbf{R}^{\mathbf{2}}\right)$}

Koefisien ini nilainya antara 0 (nol) sampai dengan 1 (satu).Semakin besar nilai koefisien tersebut maka variabel-variabel independen lebih mampu menjelaskan variasi variabel dependen. Nilai koefisien determinasi merupakan suatu ukuran yang menunjukkan besar sumbangan dari variabel independen terhadap variabel dependen, atau dengan kata lain koefisien determinasi mengukur variasi turunan $\mathrm{Y}$ yang diterangkan oleh pengaruh $\mathrm{X}$. Bila nilai koefisien dterminasi yang diberi symbol $R^{2}$ mendekati angka1, maka variabel independen makin mendekati hubungan dengan variabel dependen (Gujarati, 2009).

Adapun kegunaan koefisien determinasi adalah:

1. Ukuran mengukur proporsi atau presentase dari jumlah variasi yang diterangkan oleh model regresi atau untuk mengukur besar sumbangan dari variabel $\mathrm{X}$ terhadap variabel $\mathrm{Y}$.

2. Hasil dari analisis ini dinyatakan dalam presentasi batas-batas determinasi sebagi berikut : $0<r^{2}<1$.

3. Untuk mengetahui nilai koefisien determinasi, mak dapat dihitung dengan cara mengkuadratkan nilai koefisien korelasi $\left(r^{2}\right)$.

\section{HASIL PENELITIAN DAN PEMBAHASAN}

\section{Hasil Penelitian}

\section{Hasil Analisis Regresi Liniear Berganda}

Regresi liniear berganda bertujuan untuk mengetahui ada tidaknya pengaruh signifikan dua atau lebih variabel bebas terhadap variabel terikat (Y). Untuk melihat ada tidaknya pengaruh dapat dilihat melalui uji asumsi klasik.

\section{Hasil Uji Normalitas}

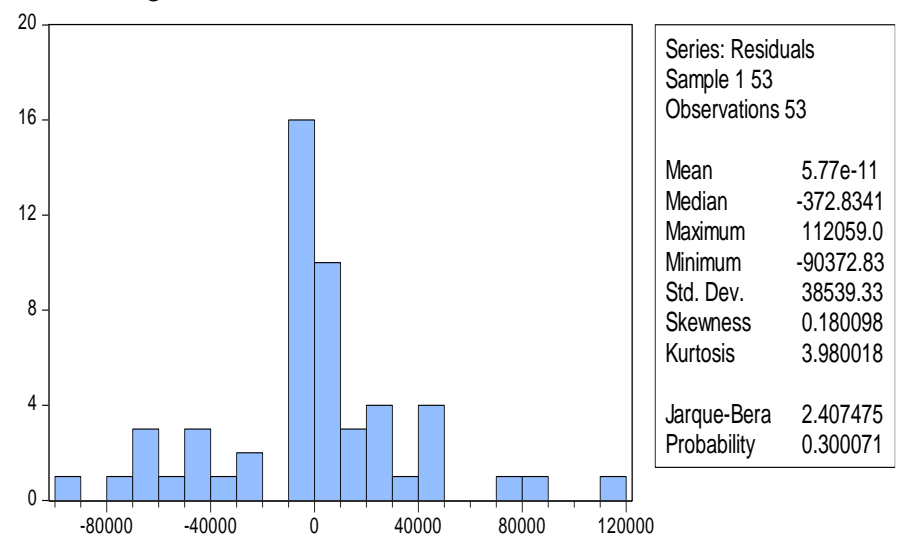

Sumber: Data Diolah (2019)

\section{Gambar 2}

\section{Histogram-Hasil Uji Normalitas}

Untuk mengetahui normal atau tidak normalnya model regresi variabel pengganggu yaitu dengan cara membandingkan nilai J-B dengan $\mathrm{X}^{2}$ Chisquare tabel dengan $\mathrm{df}=53-4=49$, dan $\alpha=5 \%$ adalah sebesar 1,67655. Kemudian nilai probability sebesar 0.300071>0.05 sehingga dapat diartikan bahwa data berdistribusi normal. 


\section{Hasil Uji Asumsi Klasik}

Berikut hasil uji asumsi klasik :

\section{Hasil Uji Autokorelasi}

Adapun hasil pengujian sebagai berikut :

\section{Tabel 2}

\section{Hasil Uji Autokorelasi}

Breusch-Godfrey Serial Correlation LM
Test:

\begin{tabular}{lrll}
\hline \hline & & & \\
& 0.5648 & & \\
F-statistic & 81 & Prob. F(2,47) & 0.5722 \\
Obs ${ }^{*}$ - & 1.2440 & Prob. Chi- & \\
squared & \multicolumn{2}{c}{8 Square(2) } & 0.5368 \\
& & & \\
\end{tabular}

Sumber: Hasil Olah Data,2019

Berdasarkan hasil Tabel 2 diatas dapat dilihat dari nilai prob. Chi-Square sebesar 0.5368> 0.05 maka mengindentifikasikan bahwa data tidak mengandung masalah Autokorelasi.

\section{Uji Multicoliniearitas}

Adapun hasil pengujian sebagai berikut :

Tabel 3

Hasil Uji Multicoliniearitas

\begin{tabular}{|c|c|c|c|}
\hline & $\mathrm{X} 1$ & $\mathrm{X} 2$ & $\mathrm{X} 3$ \\
\hline $\mathrm{X}$ & 1 & 0.528057 & 0.486969860 \\
1 & & 72960980 & 0508987 \\
& & 63 & \\
\hline $\mathrm{X}$ & 0.5280577 & 1 & 0.391089469 \\
2 & 29609806 & & 924161 \\
& 3 & & \\
\hline $\mathrm{X}$ & 0.4869698 & 0.391089 & 1 \\
3 & 60050898 & 46992416 & \\
& 7 & 1 & \\
\hline
\end{tabular}

Sumber : Hasil Olah Data,2019

Berdasarkan hasil uji multikolinearitas menunjukkan bahwa tidak terdapat variabel yang memiliki nilai lebih dari 0,8 . Dengan demikian dapat disimpulkan bahwa dalam penelitian ini tidak terjadi multikolinearitas.

\section{Hasil Uji Hipotesis}

Adapun hasil pengujian yaitu :

Tabel 4

Hasil Uji Regresi Liniear Berganda

\begin{tabular}{cc}
\hline \hline Variable & $\begin{array}{c}\text { Coefficie } \\
\text { ntStd. Error t-Statistic Prob. }\end{array}$ \\
\hline \hline C & 34176.8 \\
529530.551 .157339 & 0.2527
\end{tabular}

0.05434

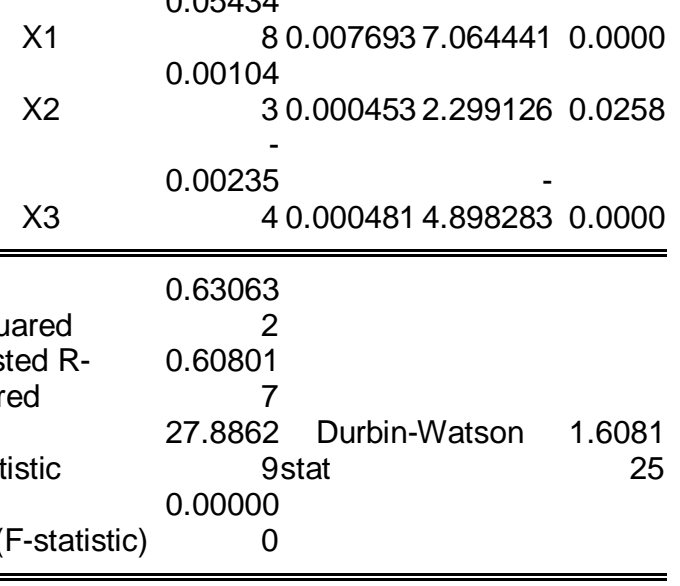

Sumber: Hasil Olah Data, 2019

Dari hasil diatas dapat di interpretasikan hasil Analisis Regresi Linear Berganda yaitu sebagai berikut:

(NilaiProduksi) $=34176,85+0,054348$

(Biaya

Tenaga Kerja) + 0,001043 (NilaiInvestasi) 0,002354 (Biaya Bahan Baku).

Dari hasil Analisis Regresi Linear Berganda yaitu sebagai berikut:

1. Konstanta sebesar 34176,85 menunjukkan apabila $\left(\mathrm{X}_{1}\right),\left(\mathrm{X}_{2}\right), \quad$ dan $\quad\left(\mathrm{X}_{3}\right)$ bernilai (konstan) maka (Y) juga akan konstan sebesar Rp.34.176,85.

2. Koefisien $\left(X_{1}\right)$ mempunyai nilai sebesar Rp.0,054348, Hal ini menunjukkan hubungan positif. Artinya apabila $\left(\mathrm{X}_{1}\right)$ meningkat Rp.1 maka (Y) juga akan meningkat sebesar Rp.0,054

3. Koefisien variabel $\left(\mathrm{X}_{2}\right)$ mempunyai nilai sebesar Rp.0,001043. Hal ini menunjukkan hubungan yang positif. Artinya apabila $\left(\mathrm{X}_{2}\right)$ meningkat Rp.1 maka (Y) juga akan meningkat sebesar Rp.0,001

4. Koefisien variabel $\left(\mathrm{X}_{3}\right)$ mempunyai nilai sebesar -Rp.0,00254. Hal ini menunjukkan hubungan yang negatif. Artinya apabila $\left(\mathrm{X}_{3}\right)$ menurun Rp.1 maka (Y) akan menurun sebesar Rp.0,002.

\section{Hasil Uji t-Statistik}

Penelitian ini menggunakan uji $\mathrm{t}$ sebagai pengujian Hipotesis. Uji t digunakan untuk melihat pengaruh variabel independen terhadap variabel dependen secara parsial. Adapun kriteria 
pengambilan keputusannya yaitu dengan melihat nilai $t_{\text {hitung }}$ dengan membandingkannya dengan nilai $t_{\text {tabel }}$ kemudian juga melihat nilai signifikansinya. Berdasarkan hasil pengujian secara Parsial pada Tabel 4 dapat dijelaskan sebagai berikut:

1. Variabel $\left(\mathrm{X}_{1}\right)$ berpengaruh secara signifikan dan positif terhadap (Y). Hal ini didasarkan pada nilai $t_{\text {hitung }}>t_{\text {tabel }}$ yakni 7,064 > 1,674 maka terima $\mathrm{H}_{1}$. Hal ini juga dapat dilhat dari nilai probabilitas hitung $<\mathrm{p}$ - value atau $0.000<0,05$.

2. Variabel $\left(\mathrm{X}_{2}\right)$ berpengaruh secara signifikan dan positif terhadap (Y). Hal ini didasarkan pada nilai $t_{\text {hitung }}>t_{\text {tabel }}$ yakni 2,299>1,674 maka terima $\mathrm{H}_{1}$. Hal ini juga dapat dilihat dari probabilitas hitung $<\mathrm{p}$ - value atau $0,025<0,05$.

3. Variabel $\left(\mathrm{X}_{3}\right)$ berpengaruh secara signifikan dan negatif terhadap (Y). Hali ini didasarkan pada $t_{\text {hitung }}<\mathrm{t}_{\text {tabel }}$ yakni 4,898 maka terima $\mathrm{H}_{0}$. Hal ini juga dapat dilihat dari probabilitas hitung $>\mathrm{p}$ - value atau $0,000>0,05$.

\section{Hasil Uji F-Statistik}

Priyanto (2013), mengatakan uji f digunakan untuk statistic uji $\mathrm{f}$ dengan $\mathrm{Df}_{1}=$ $(\mathrm{k}-1) \mathrm{Df}_{2}=(\mathrm{n}-\mathrm{k}-1)$. Dimana $\mathrm{f}$ tabel diperoleh dari daftar tabel distribusi f dengan $\alpha=$ 0,05. Berdasarkan hasil pengujian pada tabel diatas maka dapat dilihat bahwa nilai $F_{\text {hitung }}$ sebesar 27,886 dengan probabilitas 0,000, sedangkan $\mathrm{F}_{\text {tabel }}$ pada $\mathrm{df}=(\mathrm{k}-1)(\mathrm{n}-\mathrm{k})=(3-1)(53-$ $3)=(2)(50)$ yaitu 3,18 maka 27,88 >3,18. Dapat disimpulkan bahwa secara simultan $\left(\mathrm{X}_{1}\right),\left(\mathrm{X}_{2}\right)$ dan $\left(\mathrm{X}_{3}\right)$ berpengaruh signifikan dan positif terhadap (Y).

\section{Koefisien Determinasi $\mathbf{R}^{\mathbf{2}}$}

Koefisien determinasi dilakukan untuk melihat sebesar kemampuan variabel independen secara bersama-sama member penjelasan terhadap variabel dependen dimana $R^{2}$ berkisar antara 0 samapai $\left(0<R^{2}<1\right)$ (Gujarati, 2003).

Dari uji koefisien determinasi $R^{2}$ dengan Regresi Linear Berganda, maka yang dilihat dari
Ajudted R Square yaitu sebesar 0,6080 atau Rp.60,80. Jadi besarnya pengaruh $\left(\mathrm{X}_{1}\right),\left(\mathrm{X}_{2}\right)$ dan $\left(\mathrm{X}_{3}\right)$ terhadap $(\mathrm{Y})$ di Kabupaten Bireuen tahun 2017 adalah 60,80\% . Sedangkan sisanya di pengaruhi oleh variabel lain luar penelitian $39,20 \%$.

\section{Pembahasan}

\section{Pengaruh Biaya Tenaga Kerja Terhadap Nilai Produksi Industri Perabot}

Hasil penelitian ini menunjukkan bahwa Biaya Tenaga Kerja berpengaruh terhadap Nilai Produksi. Biaya Tenaga kerja biaya yang dikeluarkan untuk pekerja suatu alat kekuatan fisik dan otak manusia tidak dapat dipsahkan dari manusia dan ditujukan pada usaha produksi. Tenaga kerja juga dapat diartikan sebagai segala sesuatu yang mengelola sumber daya alam tersebut dengan menggunakan tenaga dari manusia atau biasa disebut sumber daya manusia. Tenaga kerja mempunyai peranan yang sangat penting dalam pembangunan ekonomi yaitu sebagai faktor produksi yang aktif untuk mengolah faktor-faktor produksi lainnya.

Hasil penelitian ini sesuai dengan penelitian Budiman (2015), yang bahwa Biaya Tenaga Kerja memiliki pengaruh positif dan signifikan terhadap pendapatan.

\section{Pengaruh Nilai Investasi Terhadap Nilai Produksi Industri Perabot}

Hasil penelitian ini menunjukkan bahwa Nilai Investasi $\left(\mathrm{X}_{2}\right)$ berpengaruh positif terhadap Nilai Produksi(Y) di Kabupaten Bireuen.

Hasil penelitian ini sejalan dengan penelitian Prasetyo \& Dkk (2005), mengemukakan bahwa investasi mempunyai pengaruh yang signifikan terhadap penyerapan tenaga kerja yang artinya semakin besar investasi yang diterima maka akan besar pula penyerapan tenaga kerja.

\section{Pengaruh Biaya Bahan Baku Terhadap Nilai Produksi Industri Perabot}

Hasil dari penelitian ini menujukkan bahwa $\left(\mathrm{X}_{3}\right)$ berpengaruh negatif terhadap (Y) di Kabupaten Bireuen. Bahan baku bagian yang intergral dari produk yang dihasilkan oleh suatu perusahaan. 
Hasil penelitian ini sesuai dengan penelitian Suartawan \& Purbadharmaja (2019), menurut penelitiannya produksi sebagai variabel yang mampu memberikan tidak berpengaruh terhadap hubungan bahan baku dan pendapatan.

\section{Pengaruh Tenaga Kerja Nilai Investasi dan Biaya Bahan Baku Terhadap Nilai Produksi Secara Simultan}

Secara simultan ketiga variabel diatas yaitu Biaya Tenaga kerja, Nilai Investasi dan Biaya Bahan Baku berpengaruh secara bersamasama. Hal ini juga dibuktikan dengan hasil Analisis Regresi yang menunjukkan bahwa dari hasil Uji Statistic F=0.000000 (<5\%) artinya maka secara bersama-sama atau simultan variabel $\mathrm{X}_{1}, \mathrm{X}_{2}$ dan $\mathrm{X}_{3}$ berpengaruh positif dan signifikan terhadap variabel $\mathrm{Y}$

\section{KESIMPULAN DAN SARAN}

\section{Kesimpulan}

Berdasarkan hasil penelitian dapat diambil kesimpulan antara lain :

1. Biaya Tenaga kerja secara parsial berpengaruh positif dan signifikan terhadap Nilai Produksi Industri Perabot di Kecamatan Jeumpa Kabupaten Bireuen.

2. Nilai Investasi secara parsial berpengaruh dan signifikan terhadap Nilai Produksi Industri perabot di Kecamatan Jeumpa Kabupaten Bireuen.

3. Biaya Bahan Baku secara parsial berpengaruh negatif terhadap Nilai Produksi Industri Perabot di Kecamatan Jeumpa Kabupaten Bireuen.

\section{Saran}

Industri Perabot, diharapkan dapat menjaga kelangsungan usahnya. Terutama dalam Tenaga Kerjanya, jumlah Tenaga Kerja sangat dibutuhkan untuk meningkatkan skala produksi Industri yang akan berimbas pada peningkatan Nilai Produksi tersebut. Dalam Perindustrian diperlukan penyesuaian dalam menentukan Nilai Produksi dengan jumlah pengeluaran yang digunakan pembelian bahan baku sehingga adanya keseimbangan antara pemasukan dari penjualn produksi dan pengeluaran dalam Biaya Bahan Baku.

Industri Perabot juga diharapkan mempertahankan kualitas dalam memproduksi barang maupun jasa, untuk kepuasan konsumen dalam menggunakan barang dan jasa dari Industri Perabot.

\section{DAFTAR PUSTAKA}

Budiman. (2015). Analisis Pengaruh Tenaga Kerja, Bahan Baku, dan Teknologi Tehadap Nilai Produksi Pada Industri Percetakan Di Provinsi Riau. Jurnal FEKON, 2(2).

Ghozali, I. (2006). Aplikasi Analisis Multivarite dengan SPSS, Cetakan Keempat. Badan Penerbit Universitas Diponegoro: Semarang.

Gujarati, D. (2003). Ekonometrika Dasar. Terjemahan Sumarno. Erlangga: Jakarta.

Gujarati, D. (2006). Ekonometri Dasar. Terjemahan: Sumarno Zain. Erlangga: Jakarta.

Gujarati, D. (2009). Dasar-dasar Ekonomitrika. Salemba Empat: Jakarta.

Hasir, A. (2013). Analisis Penyerapan Tenaga KerjaIndustri Tenun Sutera di Kabupaten Wajo. Skripsi UniversitasHassanuddin.

Mardiasmo. (2007). Perpajakan, Edisi Revisi. ANDI: Yogyakarta.

Muktianji, H. (2006). Sistem Pengendalian Persediaan Bahan Baku DalamMenunjangEfektivitas Proses Produksi. Jurnal Ilmiah Rangga Gading, 6(2), 144-177.

Prasetyo, H., \& Dkk. (2005). Manajemen. Portofolio dan Analisis Investasi. ANDI: Yogyakarta.

Prawirosentono, S. (2007). Filosofi Baru Tentang Mutu Terpadu, Edisi 2. Bumi Aksara: Jakarta.

Priyanto, D. (2013). Mandiri Belajar Analisi Data Dengan SPSS. Mediakom: Yogyakarta.

Riyanto, B. (2002). Dasar-dasar Pembelanjaan Perusahaan. Edisi 4. BPFE : Yogyakarta.

Simamora, H. (2000). Manajemen pemasaran Internasional. Salemba Empat: Jakarta.

Suartawan, I. K., \& Purbadharmaja, I. (2019). Pengaruh Modal dan Bahan Baku Terhadap Pendapatan Melalui Produksi Pengrajin 
Patumg Kayu di Kecamatan Sukasakti Kabupaten Gianyar. E-Jurnal Ekonomi Pembangunan Universitas Udayana, 6(9).

Sudarsono, H. (2007). Pengantar Ekonomi Mikro. LP3ES: Jakarta.

Sugiarto, \& Dkk. (2007). Ekonomi Mikro: Sebuah Kajian Komprehensif. PT. Gramedia Pustaka Utama: Jakarta.

Sukirno, S. (2004). Makroekonomi Edisi Ketiga. PT Raja Grafindo Persada: Jakarta.

Sukirno, S. (2012). Teori Pengantar Makro Ekonomi, Edisi Ketiga. PT Raja Grafindo Persada: Jakarta.

Sumarsono, S. (2003). Ekonomi Sumber Daya Manusia dan Ketenagakerjaan. Graha Ilmu: Yogyakarta.

Sunyoto, D. (2011). Metodelogi Penelitian Ekonomi. Cetakan Pertama. CAPS: Yogyakarta.

Tandelin, E. (2010). Portofolio dan Investasi: Teori dan Aplikasi. Edisi Pertama. Kanisius: Yogyakarta. 